\title{
Matter turnover in the oligotrophic restinga ecosystem and the importance of the key species Clusia hilariana
}

\author{
Letícia da Silva Brito ${ }^{1}$, Ulrich Irmler ${ }^{2}$, Bruno Vasconcelos Guimarães Forte ${ }^{I}$, Tatiane Pereira Xavier ${ }^{I}$ \& \\ Rodrigo Lemes Martins ${ }^{1 * \text { (D) }}$ \\ ${ }^{1}$ Universidade Federal do Rio de Janeiro, Núcleo de Pesquisas em Ecologia e Desenvolvimento Socioambiental \\ de Macaé, Av. São José Barreto, 764, São José do Barreto, 27965-045, Macaé, RJ, Brasil \\ ${ }^{2}$ University of Kiel, Institute for Ecosystem Research, Department Applied Ecology, Kiel, Schleswig-Holstein, \\ Germany \\ *Corresponding author: Rodrigo Lemes Martins, e-mail: rodr.lemes@gmail.com
}

BRITO, L.S., IRMLER, U., FORTE, B.V.G., XAVIER, T. P., MARTINS, R.L. Matter turnover in the oligotrophic restinga ecosystem and the importance of the key specie Clusia hilariana. Biota Neotropica. 18(4): e20180552. http://dx.doi.org/10.1590/1676-0611-BN-2018-0552

\begin{abstract}
Restingas are sandy areas spread along the Brazilian coast made up of a mosaic of forest and open woodland vegetation adapted to varying conditions of aridity, oligotrophy and salinity. Two vegetation types are very common in southeast Brazilian restingas, open Clusia formations and seasonally dry forest formation. Litter production and nutrient $(\mathrm{C}$ and $\mathrm{N})$ turnover were studied comparatively in forest formations and Clusia formations, in vegetation patches with and without Clusia hilariana. The results showed that the breakdown process is extremely retarded in Clusia formations, with or without $C$. hilariana, leading to $\mathrm{C}$ accumulation in the soil. Microbial and soil fauna activity is lower in Clusia formations in comparison to forest formations; patches without Clusia hilariana showed intermediate conditions regarding total matter and carbon loss. Nitrogen loss was lowest in patches without $C$. hilariana, where soil micro-organisms accumulate $\mathrm{N}$ during the decomposition process, such as in the forest. The ratio of lignin in litter and the slow release of $\mathrm{N}$ reinforce the importance of the dominant tree Clusia hilariana as a potential key species for organic matter turnover. The accumulation of organic matter under the Clusia formation vegetation may be determinant for the humus richness of some bodies of water in the restinga, demonstrating the importance of this species to the ecosystem.
\end{abstract}

Keywords: Coastal ecosystem, decomposition; litterfall, nutrient cycling, nurse plant.

\section{Ciclagem de matéria nos ecossistemas oligotróficos de restinga e a importância da espécie chave Clusia hilariana}

Resumo: Restingas são terraços arenosos dispostos ao longo da costa brasileira. Dois tipos de vegetação são muito comuns nas restingas do sudeste brasileiro, formações Clusia e formação florestal sazonalmente seca. A produção de serapilheira e o turnover de nutrientes $(\mathrm{C}$ e N) foram estudados comparativamente na formação florestal e na formação aberta de Clusia, em moitas de vegetação com e sem Clusia hilariana. Os resultados mostraram que a decomposição é muito lenta na formação de Clusia levando a acumulação de C no solo. A ação microbiana e da fauna do solo também é mais lenta nessa formação em comparação com a formação florestal; moitas sem Clusia hilariana apresentaram condições intermediárias com relação a perda de carbono total. A liberação de nitrogênio também é menor em moitas sem C. hilariana, onde os microrganismos do solo acumulam o $\mathrm{N}$ durante o processo de decomposição, como na floresta. A proporção de lignina na serapilheira e a liberação lenta de $\mathrm{N}$ reforçaram a importância da espécie dominante Clusia hilariana como uma espécie chave para o turnover da matéria orgânica do ecossistema. Por fim o acúmulo de altos teores orgânicos sob a vegetação da formação de Clusia pode ser o fator responsável pela riqueza de húmus de alguns corpos de água na restinga, demostrando a importância desta espécie para o ecossistema.

Palavras-chave: Ecossistemas costeiros, decomposição; serapilheira; ciclagem de nutrientes, planta facilitadora. 


\section{Introduction}

Approximately $70 \%$ of the Brazilian coastline is covered by restinga. Restinga is defined geomorphologically by sandy marine deposits during Quaternary changes of the sea-level (Martin et al. 1993), which form sandy coastal plains of approximately 8,000 $\mathrm{km}$ in length (Tessler \& Goya 2005). These coastal plains consist of a mosaic of bare sandy areas, sections loosely covered by low vegetation, patches of low woody vegetation, spots covered by dry or wet woods, swales, artificial channels and lagoons which originate in ancient river delta depressions (Martin et al. 1993) with or without outflow to the ocean.

Three decades of studies of restinga ecology have shown that these ecosystems are exposed to extreme micro-climatic conditions. Studies on restinga vegetation describe different plant communities determined by distinct combinations of stressful conditions such as oligotrophy, drought, temperature, salinity and flooding (Scarano et al. 2005). Plant species, which affect the nutrient content of the soils and coastal lagoons, have physiologically adapted to these extreme conditions (Dias \& Scarano 2007; Hay \& Lacerda 1984). A few sets of species are extremely dominant and, consequently, predominate the functioning of these ecosystems (Scarano et al. 2004).

Open woodlands sparsely covered by shrubs are very common in the southeast Brazilian restinga. When Clusia hilariana Schltdl. (Clusiaceae) is the dominant tree species over an area, this area is defined as a Clusia formation. This tree has attracted scientific attention in recent years because of its local role as a nurse plant in this formation due to its: (1) attraction of seed dispersers, consequently affecting seedling density and richness of the understory (Dias \& Scarano 2007); (2) high contribution to biomass production (Dias et al. 2006); and (3) for its crassulacean acid metabolism (CAM) (Scarano et al. 2005). Scarano et al. (2004) proposed a succession model for Clusia formations driven by the senescence and death of Clusia in a patch, promoting the growth of understory juveniles and a change in architecture to a short and dense vegetation type. Dias et al. (2006) and Dias (2008) described a slow development of seedlings in $C$. hilariana understory until its senescence, after that the dynamics of nutrients changes. Dias et al. (2006) indicated that $C$. hilariana may promote the accumulation of organic matter due to the relatively high production of litter with slow decomposition rates.

The present study highlights questions related to the nutrient cycling in restinga environments considering the differences between vegetation types and the influence of Clusia hilariana biomass, considering this as a key species for organic matter turnover. We aimed to understand differences in biomass production and decomposition, considering carbon and nitrogen content in litterfall and soil. The ratio of lignin in litter and the presence of macroinvertebrates on the soil were also considered as vector that interferes in matter turnover. We hypothesized that the vegetation of open areas presents lower productivity when compared to the forest formations, what is cause and consequence of nutrients availability in the soil and the litter, being the Clusia hilariana one of the most recalcitrant species, promoting differences between vegetation patches with and without $C$. hilariana.

\section{Material and Methods}

\section{Study site}

The investigation was performed in an area located in the restinga of Jurubatiba National Park, north of the city of Macaé, Rio de Janeiro State, Brazil (22 ${ }^{\circ} 15^{\prime} 47-58^{\prime}$ ' S, 41 $\left.36^{\circ} 16-27^{\prime \prime} \mathrm{W}\right)$.

The restinga vegetation in the National Park was characterized by different vegetation types with plants primarily originating from the Atlantic rain forest (Scarano 2009). Clusia formations make up 32\% of the total area in the National Park, followed by Ericaceae formations (ca. 29\%) represented by sparse herbaceous vegetation, and forest formations (ca. 16\%) that occur at the periphery of the swales, lagoons or channels (ca. 10\%) (Caris et al. 2013). Araujo et al. (1998) differentiated two forest formations: seasonally dry and long-lasting flooded forests.

Clusia formations are patchy clumped patterns of vegetation that cover approximately $40 \%$ of the area interlaced with white sandy areas (Oliveira-Galvão et al. 1990). Clusia hilariana was the dominant plant species, and was the central tree in most woody patches. Patches that had no Clusia as the central tree were covered by $\mathrm{C}_{3}$ shrubs.

The soil and subsoil consisted of light brownish marine quartz sands, excessively drained and poor in nutrients, clay, and organic matter (Hay \& Lacerda 1984). The soil composition differed in the stream and channel valleys, probably due to the deposition of silt and clay carried by running waters from outside of the restinga (Magnago et al. 2010).

Three vegetation types were studied in this investigation: two types of Clusia formations and the seasonally dry forest formation. The two types of the heterogeneous Clusia formation were woody vegetation patches: 1) dominated by Clusia and 2) without Clusia. The studied formations were disposed in an equidistant point between two lagoons (towards $2.5 \mathrm{~km}$ from Carapebus and Comprida lagoons) and approximately one kilometer from the beach. Sampling and experiments

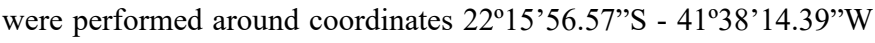
in Clusia formation and $22^{\circ} 15^{\prime} 44.98^{\prime}$ 'S - 41 $38^{\prime} 20.09^{\prime \prime} \mathrm{W}$ in seasonally dry forest formation. Patches dominated by Clusia and without Clusia were randomly distributed in an area of approximately $30.000 \mathrm{~m}^{2}$ at Clusia formation site. These two different types of patches included in the study were also in random distribution, with approximately $65 \mathrm{~m}^{2}$ (standard deviation $\pm 25 \mathrm{~m}^{2}$ ) and with a hemispherical shape.

\section{Experimental design and chemical analyses}

The study on litter production was performed from May 2012 to May 2014 (Figure 1). Fifteen replicate sites of each of the three vegetation types were selected (Figure 2). At each site, one litter sampler was installed $50 \mathrm{~cm}$ above the ground consisting of a wooden frame of $50 \mathrm{~cm}$ x $50 \mathrm{~cm} \times 15 \mathrm{~cm}$. Litter was sampled at 15 day intervals from May 2012 to April 2014, totalizing 53 samples per site. The collected litter was oven dried at $80^{\circ} \mathrm{C}$ to a constant weight and subsequently weighed (precision reading of $0.1 \mathrm{~g}$ ). The following litter fractions were weighed separately: (1) leaves, (2) wood (a set of recognized branches small than $50 \mathrm{~cm}$ ), (3) reproductive parts (flower, fruits and seeds), and (4) unidentified solid objects. Subsequently, the dried samples were stored in a freezer for later analyses. Only leaves with least than 15 days 
sampled by the litter sampler were used in this study to avoid effects of decomposition time. Leaves sampled during May 2012 to November 2012 were used for decompositions experiments, whereas samples from December 2012 to November 2013, were used for chemical analyses of carbon and nitrogen decay (Figure 1).

Temperature and precipitation data obtained from the National Institute of Meteorology (INMET) at the Macaé-Rio de Janeiro station. The climate in Macaé is characterized by hot summers (January to March) and warm winters (July to September), markedly seasonal mainly due to differences in rainfall (Folharini 2015). During our study (May 2012 to April 2014) the mean annual daytime temperature was $23.5^{\circ} \mathrm{C}, 25.7{ }^{\circ} \mathrm{C}$ in summer and $21.1^{\circ} \mathrm{C}$ in winter. Total precipitation was $640 \mathrm{~mm}$ and $140 \mathrm{~mm}$, during the summer and winter, respectively, with a mean annual sum of approximately $1060 \mathrm{~mm}$.
Original dried litter collected from May 2012 to November 2012 for the litter production study was thawed, dried and mixed. Because of the requirement for $7 \mathrm{~g}$ of dried litter for decomposition analysis, sufficient litter bags were available for distribution and decomposition analysis in only 5 randomly chosen sites within each of the three vegetation types (Figure 2). The mesh bags were closed and exposed to the soil surface in the field. To roughly differentiate between soil fauna and micro-organism effects on the litter breakdown, two types of mesh bags were used. Five (5) mm mesh size bags allowed access to all soil organisms to the breakdown process and $0.02 \mathrm{~mm}$ mesh sizes allowed only access to micro-organisms (bacteria, fungi and soil micro-fauna) (Kampichler \& Bruckner 2009). Due to differences in decomposition rate requiring more frequent sampling from the $5 \mathrm{~mm}$ bags, 12 mesh bags of the $5 \mathrm{~mm}$ size and 4 mesh bags of the $0.02 \mathrm{~mm}$ size were exposed on

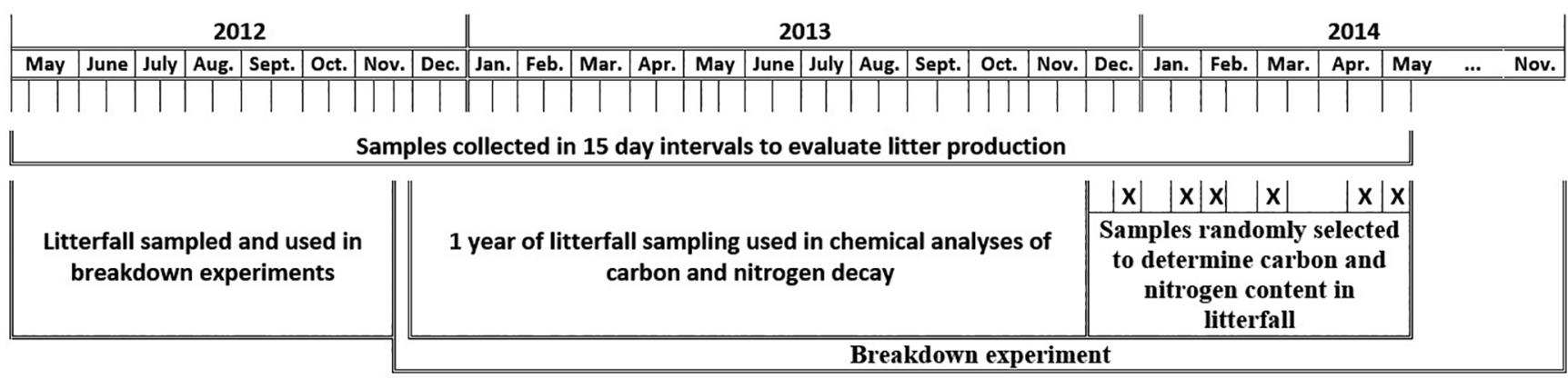

Figure 1. Sampling calendar for litterfall production, breakdown experiments and analysis of carbon and nitrogen content and decay.
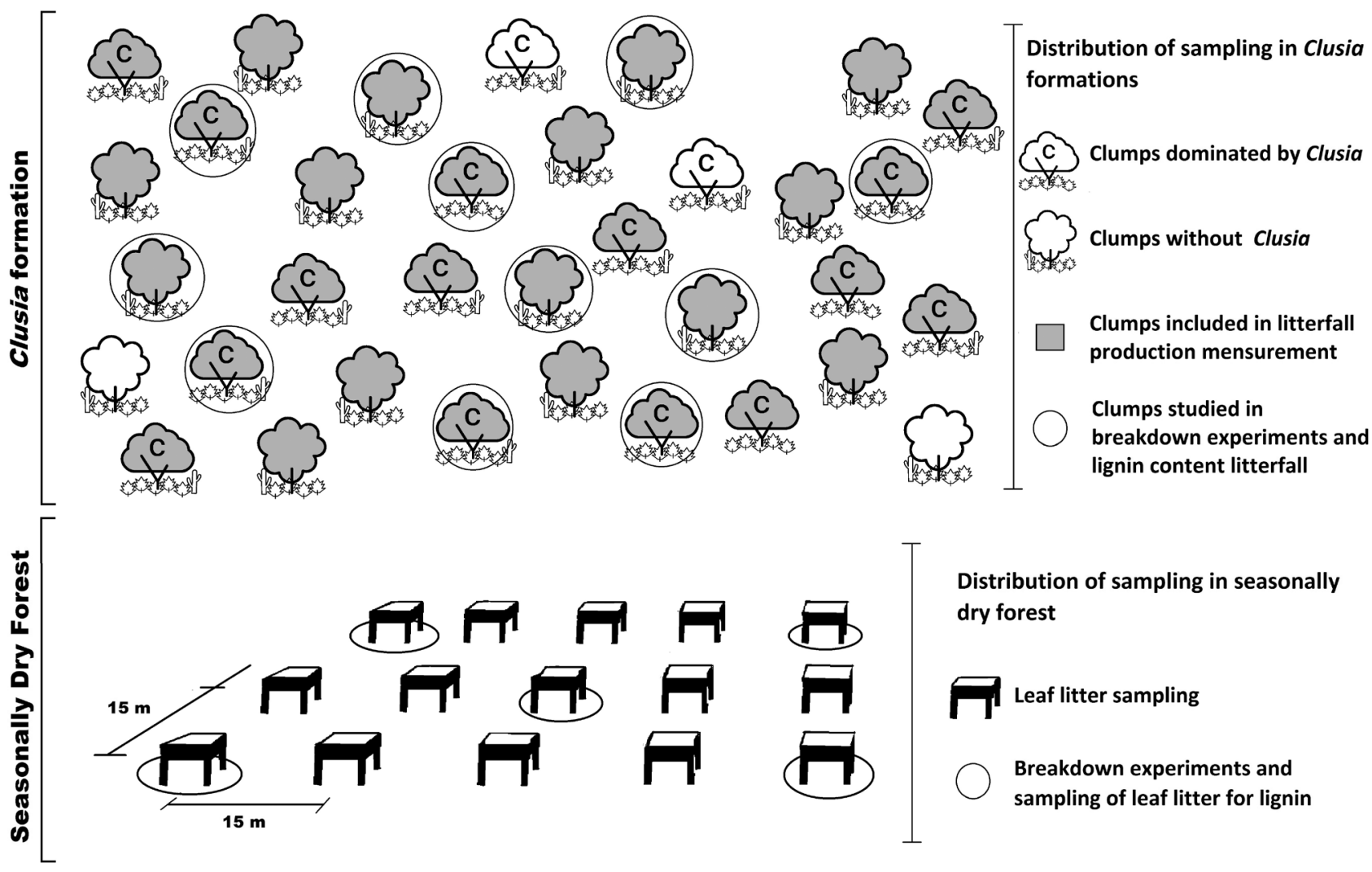

Distribution of sampling in seasonally dry forest

Leaf litter sampling

Breakdown experiments and sampling of leaf litter for lignin

Figure 2. Distribution of sampling for litterfall production, breakdown experiments and lignin content among heterogeneous Clusia formations, with and without Clusia, and seasonally dry forest. 
November $28^{\text {th }}, 2012$, at each of the 15 selected sites. The bags with 5 $\mathrm{mm}$ mesh size were successively sampled at two months intervals. The bags with $0.02 \mathrm{~mm}$ mesh sizes were sampled at 4 to 5 months intervals. The last sampling date was November $8^{\text {th }}, 2014$, approximately two years after initial exposure (Figure 1). The litter within the mesh bags was oven dried at $60^{\circ} \mathrm{C}$ for one day and weighed (precision reading of $0.1 \mathrm{~g}$ ). After weighing, the material in the mesh bags was ground to powder for the chemical analyses.

For measurement of carbon and nitrogen content in litterfall, material of one sample day was combined for five random sites of each vegetation type. This procedure was repeated six times from December 2013 to May 2014, providing six replicate samples from each of the three vegetation types (as shown in Figure 1). Total carbon was measured using a Carbon Analyser (unit TNM-1, TOC-5000, Shimadzu). Nitrogen concentration was determined spectrophotometrically using a modification of the standard Kjeldahl-N method for plant samples as described by Graça et al. (2005).

Analyses for lignin content were conducted at each of the five sites chosen for the litter breakdown experiment, considering five samples of each site as one replicate, with a total of 5 replicates per vegetation type (Figure 2). Lignin content was determined by Agrolab Group (Bruckberg, Germany) using the Acid Detergent Lignin Procedure (ADL) (according to VDLUFA 2006). Nitrogen values of the freshly fallen leaves were used to calculate the lignin/nitrogen ratio, which is considered a measure of decomposition resistance (Melillo et al. 1982).

Soil (0-10 cm depth) was physically and chemically analysed at each site of the litter breakdown experiment $(5$ replicates per vegetation type) (Figure 2) and in 5 replicate sites of the bare sandy areas between vegetation patches. Five samples of each site were mixed to one replicate sample for further analysis. The soil analyses were performed by the Soil Analyses Center of the Federal Rural University of Rio de Janeiro (UFRRJ).

\section{Statistical Analyses}

Differences in litter production, carbon and nitrogen content and lignin/nitrogen ratio between the vegetation types were statistically tested using the non-parametric Kruskal-Wallis rank test for multiple pairwise comparisons and Monte Carlo for pairwise comparison.

Friedman ANOVA was used to test the differences in the proportion of litter fractions of each vegetation type (leaves, wood, reproductive parts and unidentified). Dry litter weight and carbon content in each sample were correlated with the following sums of rainfall before litter sampling: 15, 30, and 45 days. The 15 day intervals were selected because litter sampling was also conducted at 15 day intervals. The effect of mean temperature of 15 days before litter sampling was correlated with dry litter weight considering two years of sampling. Mean of temperature were also correlated with carbon content in each sample from the second year (chemically analyzed) and linear regressions were used to test relationships between these carbon contents and litter production.

The breakdown rate was calculated using the exponential function of Olson (1963): $x_{t}=x_{0} e^{-k t}$, where $x_{t}=$ mass at time $t, x_{0}=$ mass at time $\mathrm{t}_{0}$, and $\mathrm{k}$ the breakdown rate. To compare rates, $\mathrm{k}$ was calculated for one year using the formula: $\mathrm{k}=-\ln \left(\mathrm{x}_{\mathrm{t}} / \mathrm{x}_{0}\right) /\left(\mathrm{t}_{\mathrm{t}}-\mathrm{t}_{0}\right) * 365$. Half time of litter breakdown was calculated using the formula $0.693 / \mathrm{k}$, and $95 \%$ breakdown using the formula $3 / \mathrm{k}$ (Olson 1963). The soil fauna impact was determined using the formula $\mathrm{k}_{\mathrm{f}}=\mathrm{k}_{\mathrm{tot}}-\mathrm{k}_{\mathrm{m}}$, where $\mathrm{k}_{\mathrm{f}}$ is the role of the soil fauna on the breakdown process, $\mathrm{k}_{\mathrm{m}}$ the role of the soil micro-organisms derived from the $0.02 \mathrm{~mm}$ mesh bags, and $\mathrm{k}_{\text {tot }}$ the role of all soil organisms derived from the $5 \mathrm{~mm}$ mesh bags. For the calculation of the breakdown rate at each site, the first two rates were omitted due to adaptation processes in the early period of the experiment during which bacteria and fungi are allowed time to grow and find a natural balance with micro-organism grazers. The rates were compared using a Kruskal-Wallis ANOVA with subsequent Tukey's post hoc tests, however all statistic comparisons considered data obtained until 74 weeks, when the experiments with $0.02 \mathrm{~mm}$ mesh bags was over.

Soil analyses were compared using a nonparametric Kruskal-Wallis rank test for multiple comparisons of mean ranks for all groups, followed by Monte Carlo for pairwise comparison. Statistical analyses were performed using the program PAST (Hammer et al. 2014).

\section{Results}

\section{Litter Production}

The litter production showed significant differences among seasonally dry forests and both types of Clusia formation ( $\mathrm{N}=159$, $\mathrm{df}=2, \mathrm{H}=38.23, p<0.001)$; however, no differences were observed between the two vegetation types of the Clusia formation $(\mathrm{N}=4$, $\mathrm{df}=2$, Friedman ANOVA $=1.64, p<0.05)$ (as shown in Table 1$)$. Litter production was higher in seasonally dry forests. No significant differences between litter fractions were found in the vegetation types considered.

In Clusia patches, litter production significantly increased as accumulated rainfall decreased over periods of 30 and 45 days (sum of rainfall for 30 days before litter collection: $t=-2.33, \mathrm{r}^{2}=0.096, \mathrm{df}=$ 51, $p=0.02$; and 45 days before litter collection: $t=-2.34, \mathrm{r}^{2}=0.097$, $\mathrm{df}=51, p=0.02$ ), though this relationship was not observed over a 15 day period of decreasing rainfall. No relationship between litterfall and temperature was observed within Clusia_patches. No relationship was observed between litterfall and temperature or accumulated precipitation in forest or patches without Clusia.

\section{Breakdown}

Breakdown rates were equal between the patchy sites dominated by Clusia or without Clusia, but differed between these patchy vegetation types and the forest (df: 5, Mean Squares between groups: 0.22, Mean Squares within groups: 0.01, $p<0.001$ ) (as shown in Table 2). No significant differences between mesh bags giving access to all soil organisms and those giving access only to the soil micro-organisms were found in the two patchy vegetation types. In contrast, the rates differed significantly between the two mesh bag types in the forest. With one exception, breakdown in the forest was even faster in the $0.02 \mathrm{~mm}$ mesh bags than in the $5 \mathrm{~mm}$ mesh bags for the two vegetation types of the Clusia formation. The importance of the soil fauna on the breakdown process in the forest may also be seen in the significant difference of the $\mathrm{k} f$-values between these sites and the patchy vegetation types (df: 2, MS between groups 0.11 , MS within groups: $11, p=0.04$ ) (Table 2). Regarding the time required for $95 \%$ mass loss, breakdown in the forest takes only one third as long as in the Clusia dominated sites. Even the breakdown with only microbial access to the process is two times faster in the forest than in the Clusia dominated patches with access to all soil organisms. 
Table 1. Litter characterization and Chemical and physical variables of soil $(0-10 \mathrm{~cm})$ of two formations of the Restinga de Jurubatiba National Park, Brazil. Equal superscript letters indicate insignificance difference at $p>0.05 .{ }^{1}$ Clusia formation, ${ }^{2}$ Seasonally dry forest.

\begin{tabular}{|c|c|c|c|c|c|}
\hline & Unit & ${ }^{2}$ Forest & $\begin{array}{c}{ }^{1} \text { Clusia } \\
\text { dominated }\end{array}$ & $\begin{array}{c}{ }^{1} \text { Without } \\
\text { Clusia }\end{array}$ & $\begin{array}{c}{ }^{1} \text { Areas between } \\
\text { tussocks }\end{array}$ \\
\hline \multicolumn{6}{|c|}{ LITTER } \\
\hline Content of wood & \multirow{2}{*}{$\%$} & 17.2 & 12.6 & 21.3 & - \\
\hline Reproductive parts & & 2.4 & 1.2 & 6.8 & - \\
\hline Carbon & \multirow[t]{2}{*}{ t.ha-1 $\mathrm{yr}^{-1}$} & 4.494 & 2.114 & 1.694 & - \\
\hline Nitrogen & & 0.106 & 0.029 & 0.032 & - \\
\hline Carbon & \multirow[b]{2}{*}{$\% \pm \mathrm{sd}$} & $\mathrm{a} 44.41 \pm 0.78$ & $\mathrm{a} 45.11 \pm 1.46$ & $\mathrm{a} 45.25 \pm 2.30$ & - \\
\hline Nitrogen & & ${ }^{\mathrm{b}} 1.05 \pm 0.14$ & ${ }^{\mathrm{a}} 0.63 \pm 0.13$ & ${ }^{\mathrm{a}, \mathrm{b}} 0.82 \pm 0.05$ & - \\
\hline & $\mathrm{pH} \pm \mathrm{sd}$ & a3.92 \pm 0.23 & a3.84 \pm 0.17 & $\mathrm{a}, \mathrm{b} 4.18 \pm 0.33$ & $\mathrm{~b} 4.76 \pm 0.18$ \\
\hline Sand & \multirow{3}{*}{$\mathrm{g} / \mathrm{kg}$} & 97.2 & 93.4 & 97.8 & 100 \\
\hline Silt & & 0.4 & 1.5 & 0.5 & 0 \\
\hline Clay & & 2.4 & 5.1 & 1.7 & 0 \\
\hline $\mathrm{N}$ total & \multirow{2}{*}{$\% \pm \mathrm{sd}$} & ${ }^{\mathrm{a}} 0.20 \pm 0.06$ & ${ }^{\mathrm{a}} 0.39 \pm 0.44$ & a,b $0.18 \pm 0.07$ & ${ }^{\mathrm{b}} 0.10 \pm 0.02$ \\
\hline $\mathrm{C}$ & & $\mathrm{a}, \mathrm{b} 2.75 \pm 1.16$ & a $3.73 \pm 1.52$ & $\mathrm{a}, \mathrm{b} 3.29 \pm 2.55$ & ${ }^{\mathrm{b}} 0.19 \pm 0.05$ \\
\hline $\mathrm{OM}$ & $\mathrm{g} / \mathrm{dm}^{3} \pm \mathrm{sd}$ & $\mathrm{a}, \mathrm{b} 47.48 \pm 20.05$ & ${ }^{\mathrm{a}} 64.24 \pm 26.20$ & a,b $56.72 \pm 43.88$ & ${ }^{\mathrm{b}} 3.28 \pm 0.84$ \\
\hline S.B.* & \multirow{2}{*}{$\mathrm{cmol}_{\mathrm{c}} / \mathrm{dm}^{3} \pm \mathrm{sd}$} & $\mathrm{a}, \mathrm{b} 2.59 \pm 1.67$ & a $2.47 \pm 0.55$ & $\mathrm{a}, \mathrm{b} 2.34 \pm 0.45$ & ${ }^{\mathrm{b}} 0.38 \pm 0.14$ \\
\hline $\mathrm{T}^{* *}$ & & ${ }^{\mathrm{a}, \mathrm{b}} 15.11 \pm 8.33$ & a $23.27 \pm 12.64$ & $\mathrm{a}, \mathrm{b} 15.18 \pm 16.71$ & ${ }^{\mathrm{b}} 0.38 \pm 0.14$ \\
\hline
\end{tabular}

* sum of the bases $(\mathrm{Ca}+\mathrm{Mg}+\mathrm{K}+\mathrm{Na})$; ** cation-exchange capacity at $\mathrm{pH} 0.7$.

Table 2. Breakdown rates (k) with half time and time for $95 \%$ breakdown (years) in three vegetation types in the Restinga of Jurubatiba National Park, Brazil; equal superscript letters indicate insignificance difference at $p>0.05$. ${ }^{1}$ Clusia formation, ${ }^{2}$ Seasonally dry forest.

\begin{tabular}{|c|c|c|c|c|c|c|}
\hline & \multicolumn{2}{|c|}{${ }^{1}$ Clusia dominated } & \multicolumn{2}{|c|}{${ }^{1}$ without Clusia } & \multicolumn{2}{|c|}{${ }^{2}$ Forest } \\
\hline & Mean & s.d. & Mean & s.d. & Mean & s.d. \\
\hline $\mathrm{k}_{\text {tot }}$ & ${ }^{\mathrm{a}} 0.24$ & 0.03 & ${ }^{\mathrm{ab}} 0.33$ & 0.02 & ${ }^{\mathrm{c}} 0.76$ & 0.25 \\
\hline $\mathrm{k}_{f}$ & ${ }^{\mathrm{a}} 0.02$ & 0.05 & ${ }^{\mathrm{a}} 0.11$ & 0.05 & ${ }^{\mathrm{b}} 0.33$ & 0.29 \\
\hline Half time $_{t o t}$ & 2.91 & 0.35 & 2.09 & 0.11 & 0.91 & 0.23 \\
\hline $95 \%_{t o t}$ & 12.6 & 1.5 & 9.0 & 0.5 & 3.9 & 1.0 \\
\hline $95 \%_{m}$ & 13.5 & 2.4 & 13.3 & 2.2 & 6.2 & 0.3 \\
\hline
\end{tabular}

tot rates for $5 \mathrm{~mm}$ mesh bags; $m$ rates for $0.02 \mathrm{~mm}$ mesh bags; $f$ part of soil fauna on breakdown.

\section{Carbon and Nitrogen Turnover}

Carbon in litter was not correlated with the variations in litter production or with the climatic variables considered. Carbon concentrations were statistically similar in all vegetation types (as shown in Table 1). Nitrogen and lignin/nitrogen ratios were significantly different between Clusia dominated shrub patches and forest, with these levels being intermediate in shrub patches without Clusia (Table 1). Though nitrogen level was significantly lower in Clusia dominated patches than in forest vegetation, relatively high levels of lignin resulted in a significantly higher ratio of lignin/nitrogen in Clusia dominated patches than in forest vegetation.

Carbon loss in the litter bags may be separated into three processes: loss of $\mathrm{C}$ by microbial respiration and loss of stable $\mathrm{C}$ matter by food uptake of soil fauna or transportation to deeper soil layers. The succession of carbon turnover showed that carbon concentration decreased during the breakdown process (see Figure 3). At the end of the experiment, carbon concentration was approximately $93 \%$ of the initial concentration in the forest but approximately $99 \%$ of the initial concentration in the two patches of the Clusia formation (as shown in 
Table 3). Total carbon loss was approximately $25 \%$ for both 0.02 and 5 $\mathrm{mm}$ mesh bags in the patches dominated by Clusia and approximately $45 \%$ in $0.02 \mathrm{~mm}$ mesh bags versus $60 \%$ in $5 \mathrm{~mm}$ mesh bags placed within the forest (Table 3). In the forest, approximately $10 \%$ of the total $70 \% \mathrm{C}$ loss could be attributed to loss by concentration and another $10 \%$ to the soil fauna activity. In the Clusia dominated patches, approximately $1 \%$ of the total $35 \%$ could be attributed to loss by concentration without any additional effect of the soil fauna. Intermediate processes occurred in the patches without Clusia but were not significantly different from the patches dominated by Clusia. Nevertheless, regarding the total $\mathrm{C}$ loss, the faunal effect seemed to be higher than in the patches dominated by Clusia (as shown in Table 3 ).

The nitrogen process was very different compared to the carbon process. A loss of approximately $50 \%$ of total nitrogen content was detected in the Clusia dominated patches, whereas an increase of nitrogen was exhibited in the patches without Clusia and in the forest (as shown in Table 3). No differences were observed between large mesh bags and fine mesh bags. The decrease in $\mathrm{N}$ concentration in the Clusia dominated patches indicated that micro-organisms were inhibited and could not accumulate nitrogen in their biomass. In contrast, micro-organisms accumulated nitrogen higher than the initial values in the two other systems and, thus, reduced losses in comparison with Clusia dominated patches (see Table 3 and Figure 4a). Soil fauna was at least partly responsible for a slight nitrogen release in these two systems as could be seen by the differences between the two mesh bags.

The breakdown process showed that the nitrogen losses occurred mainly during the first weeks (see Figure 4). However, losses in the Clusia dominated patches lasted longer than in the forest, which indicated that the growing process of micro-organisms in the Clusia patches was slower than in the forest. After this initial process of nitrogen concentration loss, the accumulation process started in the forest, whereas under Clusia only a steady state level was exhibited.

\section{Soil}

Patches with Clusia showed higher nutrient content and higher proportions of silt and clay; leaching was probably less than in other areas with higher sand content. However, differences were only significant for the bare sandy areas in the Clusia formation (as shown in Table 1). Nitrogen and $\mathrm{pH}$ in the forest also exhibited significantly higher values when compared with the bare sandy areas.

\section{Discussion}

Results showed that litter production differed between forest and Clusia formations and that this difference would be even greater, if the area which was actually covered by vegetation was taken into account. In the Clusia formation, only approximately $40 \%$ is covered by vegetation, whereas the whole area is covered by vegetation in the forest (Oliveira-Galvão et al. 1990). These differences in production between restinga vegetation types have also been found in previous studies, e.g. maximum values of production $\left(\mathrm{t} \mathrm{ha}^{-1} \cdot \mathrm{yr}^{-1}\right)$ and their respective percentage of leaves fractions were: $4.5-66 \%$ in patches with Clusia (Silva et al. 2005) and $7.7-73 \%$ on periodically dry forests (Brietz et al. 2005). Litter production in the investigated forest was higher than in those reported by Brietz et al. (2005) and Silva et al. (2005). They were, however, in agreement with productions for equatorial areas, e.g. 10.9 t. ha ${ }^{-1} \cdot \mathrm{yr}^{-1}$ and $62 \%$ of leaves (Bray \& Gorham 1964) and forests established on soils of moderate fertility of the Atlantic Forest, with a mean of $9.1 \pm 1.24$ t. ha-1 $\cdot \mathrm{yr}^{-1}(\mathrm{n}=5)$ (Morellato 1992). The values obtained for the Clusia formation were similar to values reported for other Brazilian ecosystems with oligotrophic soils, scleromorphisms and seasonality, such as in both the Cerrado and Caatinga, with 3.2 and 5.1 t. ha $^{-1} \cdot \mathrm{yr}^{-1}$, respectively (Pires et al. 2006).

Differences in productivity of vegetation types contributed to dissimilarities in the vegetation composition driven by stressful abiotic conditions (Hay \& Lacerda 1984; Scarano et al. 2004). The differences in plant productivity and the response to rainfall events in patches with and without Clusia endorse the relative importance of vegetation composition for litter production. Variation of litter production in patches dominated by Clusia was described as seasonally variable by Silva et al. (2005), who reported highest litter production at the end of the dry season in September. Results obtained in the current study do not suggest a well-defined periodicity on litter production, but a cumulative effect of drought. In the restinga, rainfall scarcity strongly affects water table levels, which are directly determined by the levels of coastal lagoons and the tide in coastal areas (Magnago et al. 2013; Umbelino 2008).

Nitrogen in the litter leaves was very low; values for Clusia formation were lower than the mean found for tropical forests on Spodosols and sandy soils $\left(0.048\right.$ t.ha $\left.^{-1} \cdot \mathrm{yr}^{-1}\right)$, while the seasonal dry forest reaches values closer than found for tropical forest on infertile soils $\left(0.108\right.$ t.ha $\left.^{-1} . \mathrm{yr}^{-1}\right)$ (Vitousek \& Sanford 1986). Mean values of

Table 3. Carbon and nitrogen concentrations (\% of original C, N) and losses at the end of the 74 weeks with results of the ANOVA and Tukey's post-hoc test; equal superscript letters indicate insignificance difference at $p>0.05 .{ }^{1}$ Clusia formation, ${ }^{2}$ Seasonally dry forest.

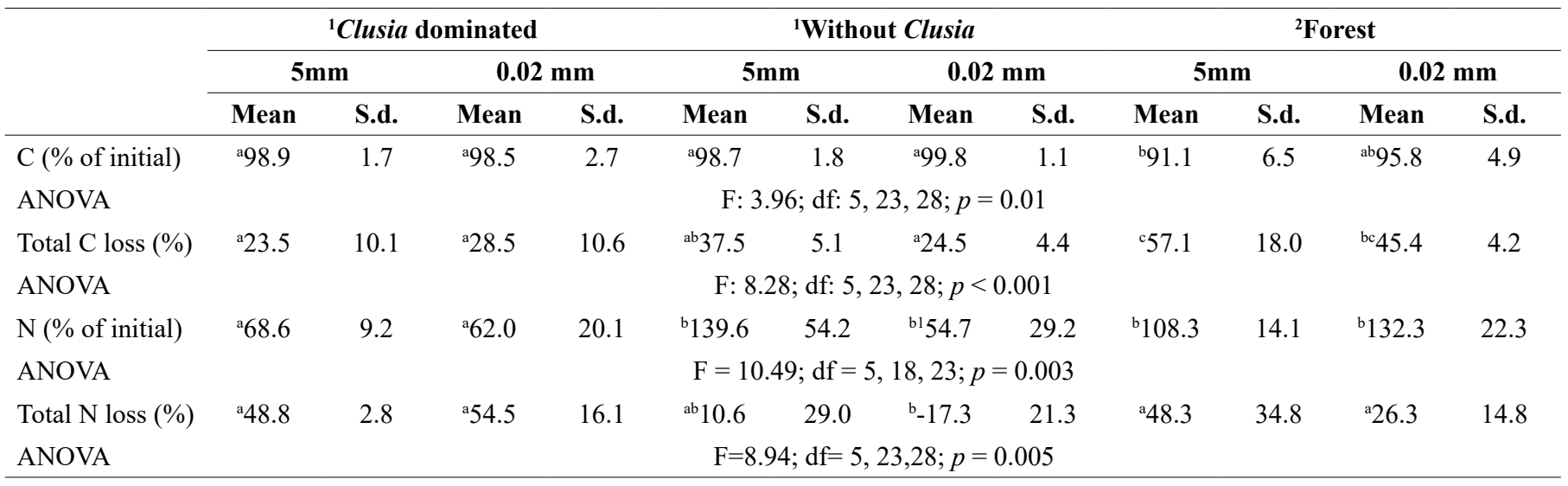




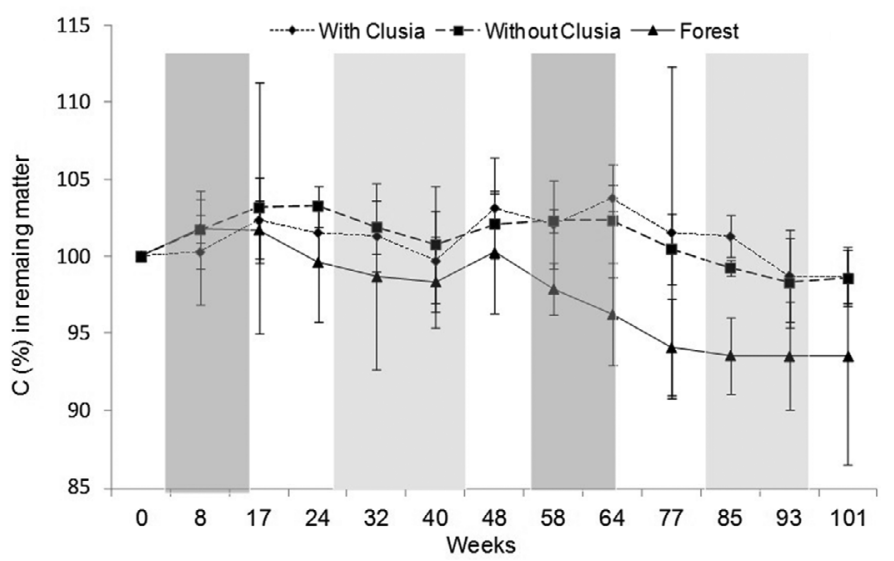

Figure 3. Carbon concentration during the breakdown process in $5 \mathrm{~mm}$ mash bags showing different patterns for vegetation patches dominated by Clusia and without Clusia, and for Seasonally dry forest. Bars indicate standard deviation; dark grey: main rainy season, light grey: main dry season.
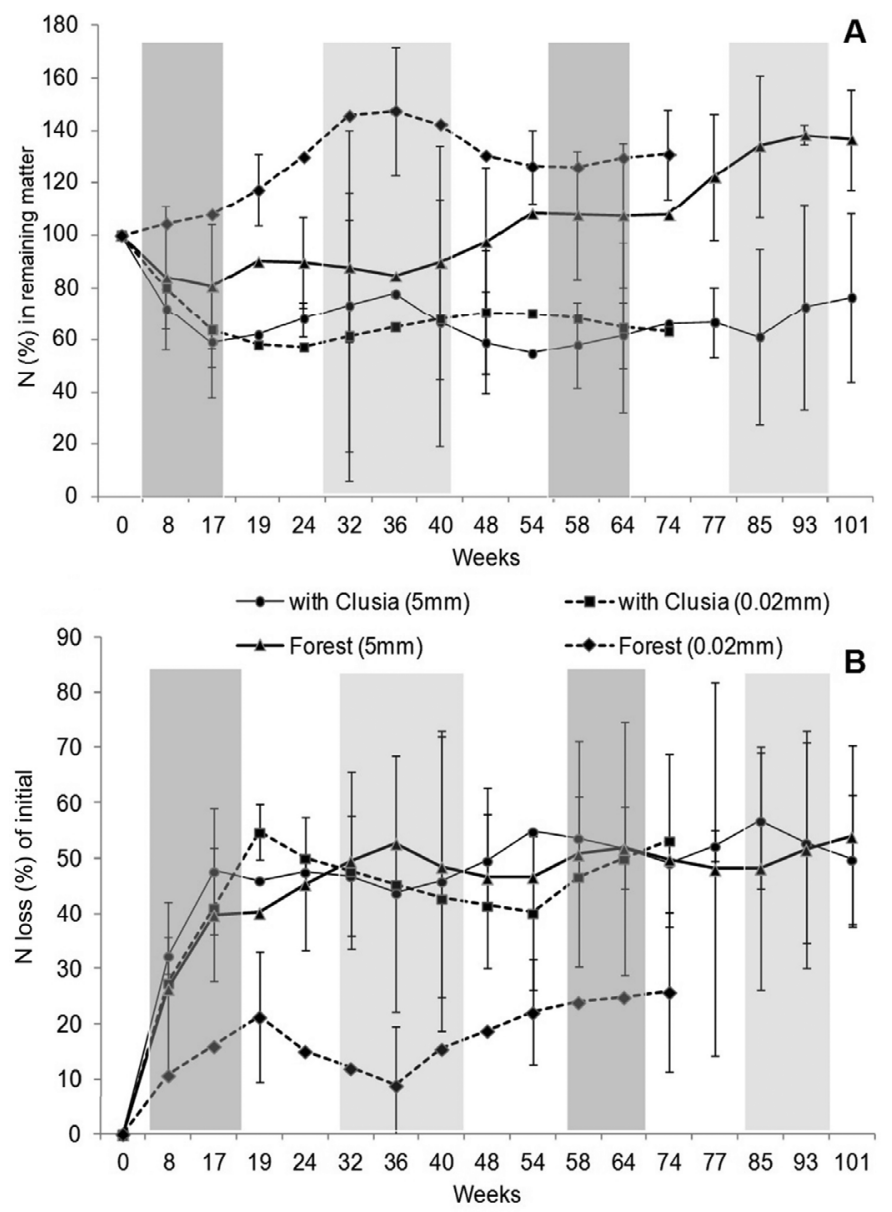

Figure 4. Nitrogen concentration during the breakdown process (A) and loss of nitrogen during the breakdown process (B).

nitrogen concentration in leaf litter of tropical plants were $1.46 \% \pm$ 0.88 (Aerts 1997). However, Dias (2008) studied five species from the Clusia formation and found lower values, with means of $0.79 \% \pm 0.19$. According to Vitousek \& Sanford (1986) the amount of nutrient cycling in regions of high productivity was high, whereas forests on the poor sandy soils were more efficient in cycling lower quantities of nitrogen.
Litter breakdown of restinga forests as well as nearby Atlantic and semi-deciduous forests in the São Paulo region was investigated by Castanho et al. (2012). These authors used different models to calculate the k-value. Their single exponential model was equal to the model used here. According to this model, the yearly k-values ranged between 2.0 and 2.9 which were much faster than values found in the forests of the restinga ecosystems investigated here, with $\mathrm{k}$ values of 0.24 to 0.76 . The $95 \%$ breakdown in the São Paulo region lasted only 1.0 to 1.4 years in comparison to 13 years in the restinga of Jurubatiba National Park. This difference might be attributed to higher precipitation in the São Paulo region without dry seasons or with shorter dry seasons than in the currently investigated area. Litter breakdown in the Atlantic forest was also investigated by Gießelmann et al. (2010), who found strong effects for the composition of plant species. According to the k-values given by Gießelmann et al. (2010), 95\% breakdown in the Atlantic forest ranged from 0.7 to 4 years depending on the leaves of the plant species. Only the investigated seasonally dry forest was in the range of the values found in the Atlantic forest. Castanho et al. (2012) and Gießelmann et al. (2010) also emphasized that, in general, the exclusion of invertebrates decreased litter decomposition but the effect depended mainly on litter composition. These results correspond with our findings in the restinga ecosystem where invertebrates only affect the breakdown in the forest formation but not in the Clusia formation. Peña-Peña \& Irmler (2016) investigated hard-leafed Cerrado forests and found significant differences between dry and rainy seasons. They found $95 \%$ decay after 1 year for the rainy season and $7.6 \mathrm{yr}$ for the dry season. Much lower effects of $6 \%$ to $13 \%$ were found by Vasconcelos et al. (2007) in their dry season irrigation experiment under the wetter conditions of eastern Amazonia. However, a periodical change in the course of the litter breakdown in the investigated restinga was only found in the forest formation.

The relation between nitrogen and carbon during the breakdown process showed that the Clusia dominated patches distinctly differ from the processes occurring in the other two sites. Under Clusia, the microbial soil system grew slowly and needed at least half a year to keep the nitrogen at a steady state level. The microbial soil system was not able to accumulate nitrogen during the decomposition of carbon at the beginning of the process. The micro-organisms in the two other systems grew faster and were able to accumulate nitrogen quickly, which contributed to the incorporation of nitrogen in the micro-organisms (Aber \& Melillo 1982). According to Aber \& Melillo (1982), this process was also related to the lignin content in the litter. Thus, Clusia seems to affect the whole decomposition process including the microbial potential and its effect on the immobilization of nitrogen (Bosatta \& Staaf 1982). The ability to accumulate nitrogen in the microbial systems of the non-Clusia patches and the forest were responsible for the higher decomposition and losses of carbon in these systems. Soil fauna was also responsible for 20 to $30 \%$ nitrogen release during the late breakdown process in the forests. Anderson et al. (1983) found several soil fauna groups that accelerated the nitrogen release in litter, but Collembola were the most effective group. According to Irmler (2000), soil fauna only mediated the release of nitrogen between micro-organisms and roots.

Meentemeyer (1978) stated that lignin concentration and actual evapotranspiration are the main drivers controlling the litter decomposition. Thus, a main factor for the slow breakdown in the Clusia formation may be the high lignin concentration and the high 
lignin/ $\mathrm{N}$ ratio of leaves. Castanho $\&$ de Oliveira (2008) reported similar values of lignin for another Clusiaceae, Calophyllum brasiliense, with approximately $48 \%$ lignin and a lignin/ $\mathrm{N}$ ratio of 62.7 , which was by far the highest lignin concentration of their investigated plants in southern Brazil. These were distinctly lower than in the Clusia dominated patches, with a lignin/ $\mathrm{N}$ ratio of 73.4. The breakdown in the restinga investigated by Castano \& de Oliveira (2008) was still faster than in the Cerrado. Thus, the slow breakdown rates in the Clusia formation without seasonal changes may be attributed to high lignin concentrations of Clusia leaves as well as to the poor sandy soils, which cause extreme physiological constraints throughout the year.

According to Dias et al. (2006), C. hilariana is also of great importance due to its higher production of biomass in the nutrient-poor coastal vegetation. Approximately $65 \%$ of the litter in patches dominated by $C$. hilariana were composed of leaves of this species (Silva et al. 2005), which was twice as much leaf biomass of $C$. hilariana in litter composition than on the live biomass stock (Dias et al. 2006). The oligarchic structure of the Clusia formation suggests that this community is driven to a high extent by Clusia hilariana, although obtained data have found no significant differences in the nutrient production between patches with and without Clusia. The present study suggests that this species also affects nutrient cycling, promoting a slow release of nutrients important for the development of understory plants in the oligotrophic soil of the restinga. However, the inhibition of microbial and soil fauna activity that minimize matter loss in patches with Clusia hilariana is combined with losses of $\mathrm{N}$ concentration, and is likely due to leaching processes in the rainy season after leaf fall. Overall, the $\mathrm{N}$ losses were higher in patches without Clusia hilariana but less than in those in the forest. Thus, for inhibition of nitrogen losses, the patches without Clusia hilariana were more efficient than the patches with Clusia hilariana. After two years of decomposition, $\mathrm{N}$ losses in the patches with Clusia hilariana amounted to approximately $50 \%$, which is similar to the forest. Nearly no $\mathrm{N}$ loss was observed in the patches without Clusia hilariana. It is still not clear which role these plants play in $\mathrm{N}$ uptake. In contrast to the patches without Clusia, the lower immobilization of $\mathrm{N}$ by soil micro-organisms facilitated the $\mathrm{N}$ uptake by plants in the patches with Clusia from the released $\mathrm{N}$ at the beginning of the decomposition process. Thus, plants in the patches without Clusia might suffer $\mathrm{N}$ deficits.

The long-lasting decomposition process in the Clusia formation leads to carbon accumulation in the soil, which may be seen in the high carbon contents, particularly under patches with Clusia plants, which is approximately twice as high as in the forest formation. The $\mathrm{C}$ accumulation might also be responsible for the input of humic substances into adjacent lagoons. During the rainy season, water tables of lagoons and ground water tables rise and promote a kind of bottom-up fertilization (Brietz 1994). Suhett et al. (2004) found high concentrations of dissolved organic carbon in the restinga's water tables, with up to 168 $\mathrm{mg} \mathrm{C}^{-1}$ and $72 \%$ of the dissolved organic carbon coming from humic substances originating from the surrounding area. The accumulation of humic compounds in the water table results from continual leaching from the litter layer, which may increase the residential time of carbon since humic compounds are very refractory to decomposition (Tranvik 1998). Similar processes were already found as reason for the humus-rich water body of the Rio Negro in the Amazon basin (Klinge
1967). The development of large Podzol soils with high contents of organic matter in the upper Rio Negro seemed to be responsible for the black colour of the river. Although no Podzol soils have developed in the investigated restinga, the accumulation of high organic contents under the vegetation of the Clusia formation caused by the retarded litter decomposition may be the reason for the humus richness of some bodies of water in the restinga ecosystem (Farjalla et al. 2009).

The results describing Clusia formation as a vegetation associated to sandy soils with low amount of organic matter, commonly associated to poor vegetation with low amount of biomass. This formation is different from seasonally dry forest in which soil is formed also by clay and organic matter. Poor soil is also associated with strong competition effect, but, surprisingly, the recalcitrant character of the dominant Clusia species seems to control the turnover of matter in the system, probably due to the lignin content and its effect on nitrogen release affecting the understory growth (Dias \& Scarano 2007, Dias 2008). The biomass of this formation is structured in patches due the effect of the arboreal habit of $C$. hilariana producing layers, with a high density and species richness of seedlings underneath, probably due to the greater activity of dispersers (Dias \& Scarano 2007). Finally, the results highlight the importance of Clusia formation for restinga ecosystem and suggest that changes in water table level and the leaching should relief the nutrient control promoted by Clusia hilariana, resulting in differences between vegetation patches dynamics.

\section{Acknowledgements}

We are thankful to Malinda Dawn Henry for assistance with English language and all of the interpretations that improved the manuscript significantly. We thank Francisco de A. Esteves and Marcos P. Barros for the support of the Aquatic Ecology Laboratory at NUPEM-UFRJ. This study was funded by Fundação Carlos Chagas Filho de Amparo à Pesquisa do Estado do Rio de Janeiro (FAPERJ) (grant no. E-26/112.079/2012), Programa de Pesquisas Ecológicas de Longa Duração from Conselho Nacional de Desenvolvimento Científico e Tecnológico (PELD - CNPq) (Sitio-5, calling 59/2009), and Deutscher Akademischer Austausch Dienst (DAAD) (grant no. 90969262). Financial support was provided from Coordenação de Aperfeiçoamento de Pessoal de Nível Superior (CAPES) through a scholarship called Programa de Educação Tutorial (PET) to TPX and through master student scholarships to LSB. Collecting permissions (25574 and 50567) were granted by Instituto Chico Mendes de Biodiversidade do Ministério do Meio Ambiente (ICMBio/MMA) to study in the National Park.

\section{Authors' Contributions}

Letícia da Silva Brito - Contribution in the concept and design of the study; Contribution to data collection; Contribution to data analysis and interpretation; Contribution to manuscript preparation.

Ulrich Irmler and Rodrigo Lemes Martins - Orientation in the concept and design of the study; Contribution to data collection; Contribution to data analysis and interpretation; Contribution to manuscript preparation.

Tatiane Pereira Xavier and Bruno Vasconcellos Guimarães Forte Contribution to data collection. 


\section{Conflicts of interest}

The authors declare that they have no conflict of interest related to the publication of this manuscript.

\section{References}

ABER, J.D. \& MELILLO, J.M. 1982. Nitrogen immobilization in decaying hardwood leaf litter as a function of initial nitrogen and lignin content. Canadian Journal Botany 60(11): 2263-2269.

AERTS, R. 1997. Climate, leaf litter chemistry and leaf litter decomposition in terrestrial ecosystems: A triangular relationship. Oikos 79(3): 439-449.

ANDERSON, J.M., INESON, P. \& HUISH, S.A. 1983. The effects of animal feeding activities on element release from deciduous forest litter and soil organic matter. In New trends in soil biology (P. Lebrun, H. M. André, A. De Medts, C. Gréorire-Wibo, \& G. Wauthy, eds.). Dieu-Brichart, OttigniesLouvain-la-Neuve, p.86-100.

ARAUJO, D.S.D., SCARANO, F.R., SÁ, C.F.C., KURTZ, B.C., ZALUAR, H.L.T., MONTEZUMA, R.C.M. \& OLIVEIRA, R.C. 1998. Comunidades vegetais do Parque Nacional da Restinga de Jurubatiba. In Ecologia das lagoas costeiras do Parque Nacional da Restinga de Jurubatiba e do município de Macaé (F.A. Esteves, ed.). NUPEM-UFRJ, Macaé, p.37-62.

BOSATTA, E. \& STAAF, H. 1982. The control of nitrogen turn-over in forest litter. Oikos 39(2): 143-151.

BRAY, J.R. \& GORHAM, E. 1964. Litter production in forests of the world. Advances in Ecological Research 2: 101-157.

BRIETZ, R.M., PIRES, L.A., RESISSMANN, C.B., PAGANO, S.N., SILVA, S.M., ATHAYDE, S.F. \& LIMA, R.X. 2005. Ciclagem de nutrientes na planície costeira. In História Natural e Conservação da Ilha do Mel (M. C. M. Marques \& R. M. Brietz, eds.). Editora da Universidade Federal do Paraná, Curitiba, p.145-168.

BRITEZ, R.M. 1994. Ciclagem de nutrientes em duas florestas da planície litorânea da Ilha do Mel, Paranaguá, PR. Dissertação de mestrado, Universidade Federal do Paraná, Curitiba.

CARIS, E.A.P., KURTZ, B.C., CRUZ, C.B.M. \& SCARANO, F.R. 2013. Vegetation cover and land use of a protected coastal area and its surroundings, southeast Brazil. Rodriguesia 64(4): 747-755.

CASTANHO, C.T. \& DE OLIVEIRA, A.A. 2008. Relative effect of litter quality, forest type and their interaction on leaf decomposition in southeast Brazilian forests. Journal of Tropical Ecology 24(2): 149-156

CASTANHO, C.T., LORENZO, L. \& DE OLIVEIRA, A.A. 2012. The importance of mesofauna and decomposition environment on leaf decomposition in three forests in southeastern Brazil. Plant Ecology 213(8): 1393-1313.

DIAS, A.T.C. \& SCARANO, F.R., 2007. Clusia as nurse plant. In Clusia - a woody neotropical genus with remarkable plasticity and diversity (U. Lüttge, ed.). Springer, Heidelberg, p.55-72.

DIAS, A.T.C. 2008. O papel das espécies da restinga aberta arbustiva de Clusia no funcionamento do ecossistema. Rio de Janeiro: Universidade Federal do Rio de Janeiro, 54 p. Tese de doutorado em Ecologia.

DIAS, A.T.C., MATTOS, E.A., VIEIRA, A.S., AZEREDO, J.V. \& SCARANO, F.R. 2006. Aboveground biomass stock of native woodland on a Brazilian sandy coastal plain: estimates based on the dominant tree species. Forest Ecology and Management 2269(1): 364-367.

FARJALLA, V.F., AMADO, A.M., SUHETT, A.L. \& MEIRELLES-PEREIRA, F. 2009. DOC removal paradigms in highly humic aquatic ecosystems. Environmental Science and Pollution Research International 16(5): 531-538.

FOLHARINI, S.O. 2015. Análise geoecológica do Parque Nacional da Restinga de Jurubatiba e zona de amortecimento terrestre utilizando geoprocessamento. Dissertação de mestrado, Universidade Estadual de Campinas, Campinas.
GIEßELMANN, U.C., MARTINS, K.G., BRÄNDLE, M., SCHÄDLER, M., MARQUES, R. \& BRANDL, R. 2010. Diversity and ecosystem functioning: litter decomposition dynamics in the Atlantic Rainforest. Applied Soil Ecology 46: 283-290.

GRAÇA, M.A.S., BÄRLOCHER, F. \& GESSNER, M.O. 2005. Methods to study litter decomposition: a practical guide. Springer, Dordrecht.

HAMMER, Ø., HARPER, D.A.T. \& RYAN, P.D. 2001. PAST: Paleontological Statistics Software Package for Education and Data Analysis. Palaeontologia Electronica 4: 1-9.

HAY, J.D. \& LACERDA, L.D. 1984. Ciclagem de nutrientes no ecossistema de Restinga. In Restingas: origem, estrutura e processos (L.D. Lacerda, D.S.D. Araujo, R. Cerqueira \& B. Turcq, eds.). CEUFF, Niterói, p.459-473.

IRMLER, U. 2000. Changes in the fauna and its contribution to mass loss and $\mathrm{N}$ release during leaf litter decomposition in two deciduous forests. Pedobiologia 44(2): 105-118.

KAMPICHLER, C. \& BRUCKNER, A. 2009. The role of microarthropods in terrestrial decomposition: a meta-analysis of 40 years of litterbag studies. Biological Reviews 84: 375-389.

KLINGE, H., 1967. Podzol soils: a source of Blackwater Rivers in Amazonia. Atas do Simposio sobre a Biota Anazônica, vol. 3, Limnologia, pp. 175-125.

MAGNAGO, L.F.S., MARTINS, S.V., SCHAEFER, C.E.G.R. \& NERI, A.V. 2013. Structure and diversity of restingas along a flood gradient in southeastern Brazil, Acta Botanica Brasilica 27(4): 801-809.

MAGNAGO, L.F.S., MARTINS, S.V., SCHAEFER, C.E.G.R. \& NERI, A.V. 2010. Gradiente fitofisionomico-edafico em formacões florestais de Restinga no Sudeste do Brasil. Acta Botanica Brasilica 24(3): 734-746.

MARTIN, L., SUGUIO, K. \& FLEXOR, J.M. 1993. As flutuações de nível do mar durante o quaternário superior e a evolução geológica de "deltas" brasileiras. Boletim do Instituto de Geologia-USP 15(Publicação Especial): 1-186.

MEENTEMEYER, V. 1978. Macroclimate and lignin control of litter decomposition rates. Ecology 59(3): 465-472.

MELILLO, J.M., ABER, J.D. \& MURATORE, J.F. 1982. Nitrogen and Lignin control of hardwood leaf litter decomposition dynamics. Ecology 63(3): 621-626.

MORELLATO, L.P.C. 1992. Nutrient cycling in two southeast Brasilian forests, I Litterfall and litter standing crop. Journal of Tropical Ecology 8(2): 205-215.

OLIVEIRA-GALVÃO, A.L.C., GALVÃO, W.S. \& CARVALHO, V.C. 1990 Monitoramento da cobertura vegetal da restinga de Carapebus-Macaé (RJ), a partir de imagens orbitais. In II Simpósio de Ecossistemas da Costa Sul e Sudeste Brasileira: Estrutura, função e manejo (S. Watanabe, ed.). ACIESP, São Paulo, p.442-454.

OLSON, J.S. 1963. Energy-storage and balance of producers and decomposers in ecological systems. Ecology 44(2): 322-331.

PIRES, L.A., BRITEZ, R.M., MARTEL, G. \& PAGANO, S.N. 2006. Produção, acúmulo e decomposição da serapilheira em uma restinga da Ilha do Mel, Paranaguá, PR, Brasil. Acta Botânica Brasilica 20(1): 173-184.

PEÑA-PEÑA, K. \& IRMLER, U. 2016. Moisture seasonality, soil fauna, litter quality and land use as drivers of decomposition in Cerrado soils in SE-Mato Grosso, Brazil. Applied Soil Ecology 107: 124-133.

SCARANO, F.R., CIRNE, P., NASCIMENTO, M.T., SAMPAIO, M.C., VILLELA, D.M., WENDT, T. \& ZALUAR, H.L.T. 2004. Ecologia vegetal: integrando ecossistema, comunidades, populações e organismos. In Pesquisas de longa duração na Restinga de Jurubatiba (C. F. D. Rocha, F. A. Esteves \& F. R. Scarano, eds.). Editora Rima, São Paulo, p.77-97.

SCARANO, F.R., DUARTE, H.M., FRANCO, A.C., GEBLER, A., DE MATTOS, E.A., NAHM, M., RENNENBERG, H., ZALUAR, H.L.T. \& LÜTTGE, U., 2005. Ecophysiology of selected tree species in different plant communities at the periphery of the Atlantic Forest of SE-Brazil I. Performance of three different species of Clusia in an array of plant communities. Trees 19(5): 497-509. 
SILVA, A.S.S., VILLELA, D.M. \& SILVA, A.P., 2005. Variação anual da produção de serrapilheira em moitas de Clusia no Parque Nacional da Restinga de Jurubatiba, RJ. Congresso de Ecologia do Brasil 7: 1048.

SUHETT, A.L., MACCORD, F., AMADO, A.M., FARJALLA, V.F. \& ESTEVES, F.A. 2004. Photodegradation of dissolved organic carbon in humic coastal lagoons (RJ, Brazil). In Humic substances and soil and water environment (L. Martin-Neto, D. M. B. P. Milori, \& W. T. L. Silva, eds.). Proceedings of the $12^{\text {th }}$ International Meeting of IHSS, São Pedro, p.61-63.

TESSLER, M.G. \& GOYA, S.C. 2005. Processos costeiros condicionantes do Litoral Brasileiro. Revista do Departamento de Geografia 17: 11-23.

TRANVIK, L.J. 1998. Degradation of dissolved organic matter in humic waters by bacteria. In Aquatic Humic Substances: Ecology and Biogeochemistry (D. O. Hessen \& L. J. Tranvik, eds.). Springer, Berlin, p.259-283.
UMBELINO, L. F. 2008. Fitossociologia e variabilidade espacial e temporal da superficie frética de solos de uma formação vegetal de restinga, Carapebus, $R J$. Rio de Janeiro: Universidade Federal do Rio de Janeiro, 150 p. Tese de doutorado em Ecologia.

VASCONCELOS, S.S., ZARIN, D.J., DA ROSA, M.B.S., OLIVEIRA, F. \& DE CARVALHO, C.J.R. 2007. Leaf decomposition in a dry season irrigation experiment in eastern Amazonian rain forest regrowth. Biotropica 39(5): 593-600.

VDLUFA. 2006. Das VDLUFA Methodenbuch, Band III: Die chemische Untersuchung von Futtermitteln. 6 Erg. VDLUFA - Verlag, Darmstadt.

VITOUSEK, P.M. \& SANFORD Jr. R.L. 1986. Nutrient cycling in moist tropical forest. Annual Review of Ecology and Systematics 17: 137-167.

Received: 25/03/2018

Revised: $24 / 07 / 2018$

Accepted: 22/08/2018

Published online: 17/09/2018 